\title{
Environment-Based Curriculum Management In Primary School
}

\author{
${ }^{a}$ Nunuk Hariyati, ${ }^{b}$ Apriliani Hartini Namat \\ Educational Management Universitas Negeri Surabaya Surabaya, Indonesia
}

Corresponding e-mail nunukhariyati@unesa.ac.id

\begin{abstract}
:
Environmental education is an effort to improve the understanding and awareness of the community in seeking solutions and prevention of environmental problems. School authority in developing curriculum and designing learning, enables schools to adapt to the needs of environmental students. This study aims to identify and describe the planning, implementation and evaluation process of environment-based curriculum at SDN Lidah Kulon 1 Surabaya with a qualitative research approach. We used qualitative data analysis interactively and continuously to find out what the data describes. Data collection techniques are unstructured interviews, observation and documentation. The result of the research at SDN Lidah Kulon 1 Surabaya shows: (1) the purpose and content of the environment-based curriculum is designed by adjusting the vision, mission and objectives of the school that has high awareness and cultured-school environment, (2) the implementation of environment-based curriculum using integration system, (3) evaluation through coordination meetings to see and measure the progress, conducted by written test, oral and portfolio within three months and six months. Those three stages are the process of implementing the environment-based curriculum so that it will create and build environmental curriculum management as the basis of curriculum development, effective and efficient curriculum implementation, and also learning quality improvement and the growth of environment caring character of the student and school personnel.
\end{abstract}

Keywords: Management, curriculum, and environment

\section{INTRODUCTION}

Environment is everything contained around living things and affect the activity of living beings ${ }^{1}$. Humans are part of the environmental components that constantly influence each other. It can be seen human exploration on the environment is enormous. One thing that is encouraging for the observers and environmentalists are in part of the world community's attention to the environment and sustainability. However, it is still cause for concern is in part of the world community to act just the opposite, to exploit and even damage the environment. They tend not seem concerned with the preservation of the environment, and even continued to blindly exploit the environment they wish regardless of the adverse effects caused by activities done.

Environmental education as part of efforts to increase understanding and awareness of society in the search for solutions and prevention of environmental problems. Environmental

${ }^{1}$ Sideris, MichailCh, etc. 2015. Evaluating the Educational Environment of an International Animal model-based Wet Lab Course for Undergradute Students. Annals of Medicine and Surgery: Volume 12, Pages 8-17. management by using educational path has a strategic position, to provide a comprehensive overview according to the development of science and technology on the environment can be performed with a variety of both formal and informal approaches. Environmental education through the formal approach through school is one alternative in providing an insight to the student environment. This is in accordance with the Morino, he stated that "Finally the work ends with an invitation to educators to introduce the virtues of ecology really human in the process of training, formation and teaching inside school"2. It is the job of educators to introduce the virtues of ecology (the interrelationships between living things and the condition of the natural surroundings in the training process, the formation and teaching in schools.

Important factors that can maximize learning opportunities for children is the creation of a conducive learning environment. Learning environment in this case is everything that relates to where the learning process implemented. The

${ }^{2}$ Moreno, Ciro Hernando Parra, etc. 2011. Education for Environment Care: Contribution

Through Human ecology. Procedia Social and Behavioral Sciences: Volume 15, Pages 3912-3915 
learning environment can reflect high expectations for all children upon the success individually. Learning environment consists of two main things: the physical environment and the social environment ${ }^{3}$. The physical environment is the environment that is around students in the form of physical facilities that exist in the scope of the school and outside the school where students learn to give a sense of comfort, serenity and ease of learning. To create a friendly and comfortable environment it needs early education to children related to environmental education so that children are accustomed to foster a sense of caring and cultured environment.

Environmental education is believed to be one of the alternative solutions that effectively and efficiently in order to increase knowledge and understanding of the environment conservation. Environmental education in Indonesia still has not been a positive influence on changes in awareness and behavior of people in doing actions that benefit or favor to the people's living environment ${ }^{4}$.

According to the same source Sumardi of environmental education will not change the situation and environmental conditions in a short time, it takes time, processes and resources. On this basis, environmental education should be pursued as early as possible in order to minimize environmental damage. This is justified by Harris ${ }^{5}$ that:

To overcome this problem,
environmental knowledge
should be given to people
through programs or activities
that demonstrate the benefit they
get by taking action towards
awareness of environmental
preservation and conversation.
This is because benefit to
oneself are essential for most
people's awareness of
environmental issues to be

${ }^{3}$ Mahmuddin. 2010. Menciptakan Lingkungan Pembelajaran yang Kondusif. Online https://mahmuddin.wordpress.com/2010/02/18/men ciptakan-lingkungan-pembelajaran-yang-kondusif/. 1 Desember 2016, pukul 16.34.

${ }^{4}$ Adam, Ahmad F.B. 2014. Analisis Implementasi Kebijakan Kurikulum Berbasis Lingkungan Hidup pada Program Adiwiyata Mandiri di SDN Dinoyo 2

Malang. Jurnal Kebijakan dan Pengembangan

Pendidikan Volume 2, Nomor 2, Juli 2014.

${ }^{5}$ Abdulla and Halim. 2010. Development of

Instrument Measuring the Level of Teachers

Pedagogical Content Knowledge (PCK) in

Environmental Education. Procedia Social and

Behavioral Sciences. Volume 134, 9 June 2010 , Pages 174-178 translated into action on them.

Therefore, environment education needs to be improved in so that the environmental knowledge can be offered more effective. As Harris (2006) argued, one of the strategies for moving sentiments and behaviors toward environmental preservation is through increasing local education efforft.

Haris opinion this means that knowledge of the environment should be given to the public by demonstrating the benefits that preserve the environment. According to him this is a good strategy to improve environmental conservation through environmental education to suit the needs of the local area.

The authority of schools in preparing curriculum allows schools to adjust to the demands of students, school conditions, and conditions of the area so that schools have the opportunity to design and determine the things to be taught, the management of the learning experience, how to teach, and assess the success of teaching and learning. Based on the results of Lidah Kulon 1 Surabaya which is develop curriculum-based environment in order to allow students to learn to love the environment and achieves Adiwiyata as the best environmental basis school in Surabaya by developing various programs to love the environment as one of the programs called " SEMUT "means a minute gleaning, and various other programs again to grow the character of students who care and cultured environment.

Adiwiyata school support program implementation is managed in the form of five components that are sustainable for the draft and plan Adiwiyata continuation school programs, one of which is a curriculum-based environment. Curriculum based-environment implemented in Primary School Of Lidah Kulon 1 Surabaya is one of the components to support the implementation of school Adiwiyata by integrating environmental themes in each subject as a form of environmental knowledge to students.

Environmental education in Indonesia still has not been a positive influence on changes in awareness and behavior of people in doing actions that benefit or favor to the people's living environment ${ }^{6}$. Development curriculum based environmentally is an indicator of both assessments, Adiwiyata. Development indicators

${ }^{6}$ Adam, Ahmad F.B. 2014. Analisis Implementasi Kebijakan Kurikulum Berbasis Lingkungan Hidup pada Program Adiwiyata Mandiri di SDN Dinoyo 2

Malang. Jurnal Kebijakan dan Pengembangan

Pendidikan Volume 2, Nomor 2, Juli 2014. 
curriculum based environmentally should be developed four criteria, namely: 1) the development of cross-subject learning model; 2) the excavation and development of materials and environmental problems that exist in the surrounding community; 3) the development of learning based environment methods and culture; and 4) the development of curricular activities for the improvement and awareness of students about the environment ${ }^{7}$.

Primary School Of Lidah Kulon 1 Surabaya is one of schools that implement curriculum based environment. Delivery of content environment to the students is done through classroom learning with a variety of themes of learning to provide insight to students about the environment associated with everyday issues, as well as the students were able to observe and practice directly on environmental knowledge acquired through the plant or plants around the school.

\section{METHOD}

This study used a qualitative approach with case study design. In general, the case study is a strategy that is more suitable when the principal question of a study with regard to how or why when research have little opportunity to control the events that will be investigated, and where the focus of his research lies in the phenomenon of contemporary (present) in the context of life real ${ }^{8}$. Location of the study in Primary School Of Lidah Kulon 1 Surabaya using data collection techniques of observation, interviews and documentation.

Data analysis in qualitative research conducted since before entering the field, on the field during and after its completion in the field. Quoted from Miles and Huberman outlook means activity in qualitative data analysis performed interactively and continues over time until completion ${ }^{9}$. In this view of the qualitative data analysis runs continuously, repeating until the data is saturated, during the period of 2 months. The presence of the researchers is a key element in qualitative research. In this study, researchers act as a human instrument for researchers is the main instrument in qualitative research. Test the validity of the data in this study using techniques such as:

${ }^{7}$ TIM Adiwiya Tingkat Nasional. 2012. Panduan Adiwiyata Sekolah Peduli dan Berbudaya

Lingkungan. Jakarta: Kerjasama Kementerian Lingkungan Hidup dengan Kementerian Pendidikan dan Kebudayaan.

${ }^{8}$ Yin, Robert K. 2011. Studi Kasus: Desain dan

Metode. Jakarta: PT Raja Grafindo Persada.

${ }^{9}$ Miles, Huberman and Saldana. 2014. Qualitative

Data Analysis: A Methods Sourcebook Edition 3. California: Sage Publication, Inc.
(1) credibility, (2) transferability, (3) dependability and (4) confirmability ${ }^{10}$.

\section{DISCUSSION}

This research resulted in the corresponding three main focus is the planning, implementation and evaluation of curriculum based-environmental in Primary School Of Lidah Kulon 1 Surabaya.

A. Curriculum Based Environment Planning in Primary School Of Lidah Kulon 1 Surabaya

The findings of researchers at Primary School Of Lidah Kulon 1 Surabaya related environmentally based curriculum planning is one component of a unified whole in achieving Adiwiyata school. Since 2011 the school received an award as one of the best schools in the city of Surabaya. Adiwiyata influence on curriculum changes Primary School Of Lidah Kulon 1 Surabaya, based on the environment as an important factor to form the basis of human wisdom to behave towards the environment is through environmental education ${ }^{11}$. With the enactment of curriculum based environment then the Headmaster and stakeholders conduct coordination meetings to formulate the vision, mission, and goal-based schools by adjusting the environment as planning is to set an objective to act before the action itself environmentally based curriculum ${ }^{12}$. The aim executed according to the book Adiwiyata (2012) is realizing the school community who are responsible for the protection and management of the environment through a good school governance to support sustainable development. Referring to the manual that Primary School Of Lidah Kulon 1 Surabaya formulate the vision of the school is Excellence in Achievement, Discipline, IMTAQ, science and technology, and cultured environment with a mission to develop a curriculum that includes efforts to conserve the environment function, prevention of environmental pollution and prevent environmental damage.

Thus primary school of Lidah Kulon 1 Surabaya based curriculum environment planning on the provisions of national adiwiyata school. It is also in accordance with one of the

${ }^{10}$ Sugiyono. 2015. Metode Penelitian: Pendekatan Kuantitatif, Kualitatif, dan R\&D. Bandung: Alfabeta.

${ }^{11}$ Alpusari, Mahmud. 2013. Analisis Kurikulum Pendidikan Lingkungan Hidup Pada Sekolah Dasar Pekanbaru. Jurnal Primary Program Studi

Pendidikan Guru Sekolah Dasar Fakultas Keguruan dan Ilmu Pendidikan Universitas Riau Volume 2 Nomor 2.

${ }^{12}$ Daryanto dan Abdullah. 2013. Pengantar Ilmu Manajemen dan Komunikasi. Jakarta: Prestasi Pustakaraya. 
principles of curriculum management by explaining the principles. Rusman stated that curriculum management must direct the vision, mission, and goals, which are applied in the curriculum, the curriculum management process should be able to amplify and direct vision, mission, and goals ${ }^{13}$.

Primary school of Lidah Kulon 1 Surabaya formulate curriculum based environment planning which will be applied both in the classroom and support programs outside the classroom and extracurricular activities. One extracurricular namely the development of the aloe vera plant as icons school named "entrepreneur product" that provide learning how to manage an aloe plant into juice and nata de lidah, in addition to extracurricular have several activities that support the implementation of the curriculumbased environments such as SEMUT, clean Friday, and composter.

Research findings related to curriculum based environment planning at Primary school of Lidah Kulon 1 Surabaya more clearly be seen in the context of the diagram describe Table 3.1 below:

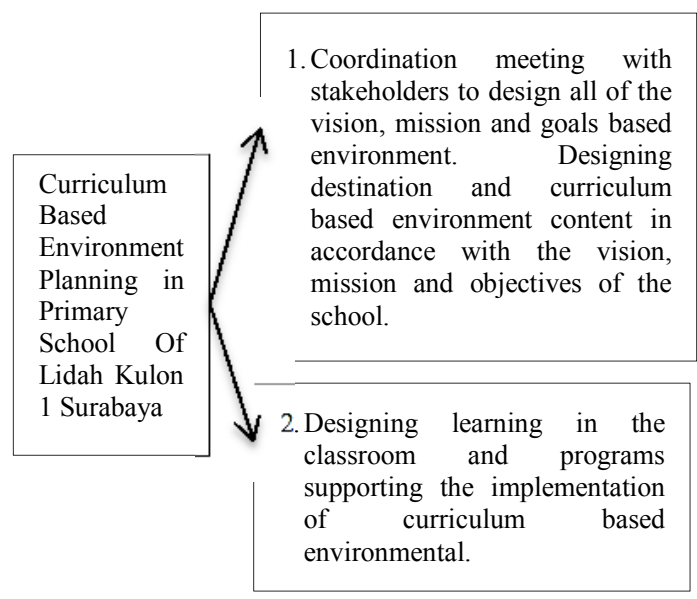

\section{B. Implementation of the Curriculum Based Environmentin Primary School Of Lidah Kulon 1 Surabaya \\ The school curriculum should not be} prepared on a separate subject, but rather a fusion number of subjects that have the same characteristics, which became a field of study (broadfield) ${ }^{14}$. Further described the type of integrative approach, which is also known as the integrated approach, the starting point of a

\footnotetext{
${ }^{13}$ Rusman. 2012. Manajemen Kurikulum. Jakarta: Rajawali Pers.

${ }^{14}$ Hamalik, Oemar. 2008. Dasar-Dasar Pengembangan Kurikulum. Bandung: Remaja Rosdakarya.
}

whole or unity meaningful and structured. Afterwards, development curriculum based environment procedures remain the same with the curriculum in general, but the material is adjusted on the material that could be integrated with the environment. Learning Implementation Plan (RPP), grating, and the syllabus of learning in the same curriculum based environment with the curriculum in general. This is in accordance with the implementation of curriculum based environment in primary school of Lidah Kulon 1 Surabaya are using the system integration by linking various subjects that exist with the problems that were found in the vicinity so that learning becomes contextual.. Then, learning gives full meaning to the learners as reflected in the wide variety of themes available, this is the same meaning-based learning environment inserted in each subject.

Implementation of curriculum based environmental must meet the following standards ${ }^{15}$ :

1. Educators develop environmental learning activities by implementing approaches, strategies, methods, and techniques of learning that actively engage learners in learning (Pakem / active learning / participatory). The findings of research through observation and interviews with informants in primary school of Lidah Kulon 1 Surabaya has implemented based learning environment and develop support programs that involve students in full. In the classroom teachers always remind students to keep the school environment and the surrounding environment, but it also provides an example of disposing of waste in place and participate in running support programs. According to one informant this strategy is one suitable form applied to elementary students because it provides stimulation to them, what he saw and observed that they also do it. However, this is not all teachers at primary school of Lidah Kulon 1 Surabaya affecting overall change in the character of students. Implementation of curriculum based environmental at primary school of Lidah Kulon 1 Surabaya can be said to be less good run in accordance with the plan, because the teacher as a facilitator or supplier curriculum to student achievement lack antuisias high attitude.

${ }^{15}$ TIM Adiwiya Tingkat Nasional. 2012. Panduan Adiwiyata Sekolah Peduli dan Berbudaya Lingkungan. Jakarta: Kerjasama Kementerian Lingkungan Hidup dengan Kementerian Pendidikan dan Kebudayaan. 
2. Students do learning activities about environmental protection and management. The results of research findings through observation, interviews and documentation explains that in learning activities about environmental protection and management of primary school of Lidah Kulon 1 Surabaya develop various programs to create the character concerned and cultured environment to the students. The program included the SEMUT, composter, dry and wet waste management, clean friday and extracurricular activities called "entrepreneur product" is managing the aloe vera plant as school icon. We have described through classroom learning theories related to the environment, the researchers also documented RPP and syllabus of learning primary school of Lidah Kulon 1 Surabaya that it is true in every subject inserted with environmental themes through an integrative approach. But the "entrepreneur product" extracurricular not all students participate, only students who have the will, even though this is a developing extracurricular school icon is all students should know the management of the aloe vera plant.

The findings related to the implementation of curriculum based environment at primary school of Lidah Kulon 1 Surabaya more clearly be seen in the context diagram Table 3.2 below:

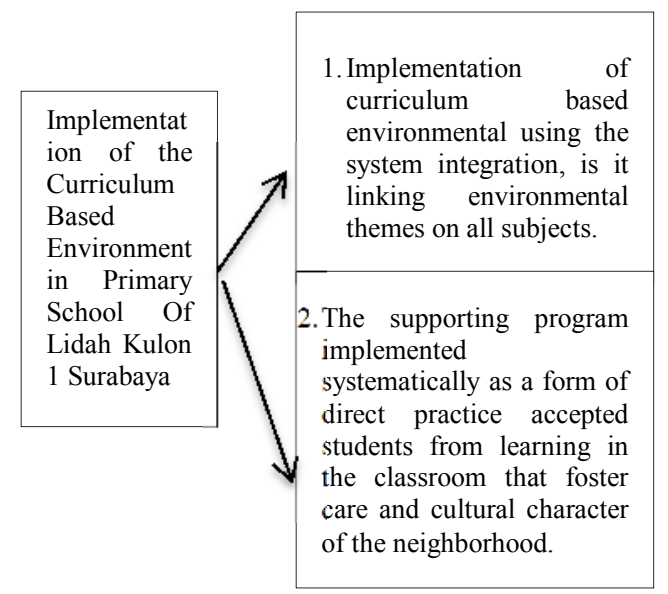

\section{Evaluation Curriculum Based Environment in Primary School Of Lidah Kulon 1 Surabaya}

There are several important considerations for a curriculum evaluator ie formative evaluation (for program improvement), and summative evaluation to decide to continue the program being evaluated or replace it with another program ${ }^{16}$. Based on this means curriculum based environmental at primary school of Lidah Kulon 1 Surabaya formative needs to be done in order to improve the program or even a summative evaluation to better quantify in detail the role of the learning environment in the classroom. Evaluation curriculum based environment in primary school of Lidah Kulon 1 Surabaya related to the evaluation of student learning outcomes in the classroom in accordance with the opinion Hamalik, namely by holding Mid Test, Exam Final, but for programs or activities undertaken outside the classroom as a supporting activity and unlike direct implementation Hamalik opinion is to do formative or summative evaluation, but according to researchers who do have effective evaluation that each held a meeting per month Headmaster always found difficult is it possible check it immediately repaired.

The educational environment is considered to be a crucial parameter that reflect directtly onto the students satiffaction, academic aspirations and overall perception of wellbeing. It is important to note that, most of the curricula are shifthing towards a studentcontered pattem, where evaluation of the educational environment has been possible through various tools, that aim to objectively measure various parameters ${ }^{17}$.

Sideris opinion above means environmental education is considered essential to meet the academic aspirations and understanding of overall students about environmental education properly so that the evaluation of environmental education enables objective measurement through curricular program students. The findings in primay school of Lidah Kulon 1 Surabaya show their support programs such as clean friday, SEMUT and extracurricular entrepreneur product provide learning to students to care and cultural environment, getting used to view the environment as a responsibility that is kept and maintained well. With a physical environment that is clean and

${ }^{16}$ Hamalik, Oemar. 2008. Dasar-Dasar Pengembangan Kurikulum. Bandung: Remaja Rosdakarya.

${ }^{17}$ Sideris, Michail Ch, etc. 2015. Evaluating the Educational Environment of an International Animal model-based Wet Lab Course for Undergradute Students. Annals of Medicine and Surgery: Volume 12, Pages 8-17. 
comfortable making the learning activities of students in the classroom and outside runs well. Through extracurricular activities that are an icon of schools increase their knowledge in the field of entrepreneurship as a provision of skills in the future. The findings related to the evaluation of environmentally based curriculum at primary school of Lidah Kulon 1 Surabaya more clearly be seen in the context diagram Table 3.3 below:

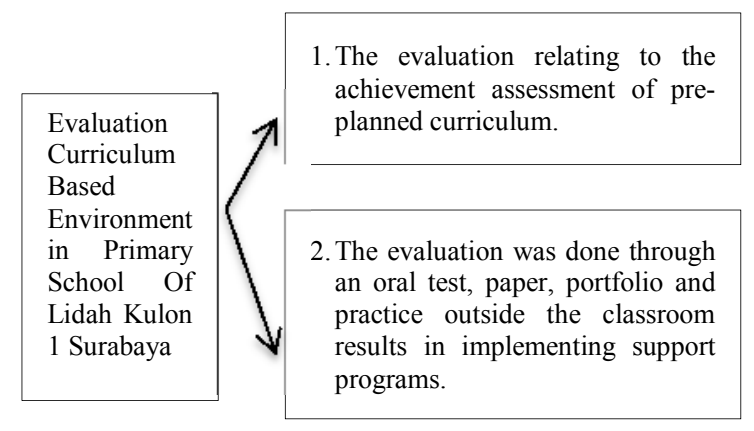

A. Conclusion

\section{CONCLUSIONS}

Based on the results of the discussions that have been described in, it can be concluded as follows:

\section{Curriculum Based Environment Planning in Primary School Of Lidah Kulon 1 Surabaya}

Curriculum based Environmental planning activities in primary school of Lidah Kulon 1 Surabaya preceded by a coordination meeting with all relevant stakeholders to discuss the school's vision, mission and goal-based school environment as well as related programs that will be implemented to support curriculum based environmental. Content of curriculum based environmental that is expected to excel in caring for the environment by adopting integration system based learning environment that is inserted in each subject based learning environment does not stand alone, but in every theme subjects of learners in the classroom.

Curriculum based Environment planning as well followed by planning support programs that is expected to create a caring attitude and cultured environment in self-learners. This support program is the implementation of a theory that has been gained in the classroom through extracurricular activities and support programs. Curriculum based environment planning on primary school of Lidah Kulon 1 Surabaya also has not varied as seen from the aspects of content matter and the development of a dynamic learning model.

2. Implementation of the Curriculum Based Environment in Primary School Of Lidah Kulon 1 Surabaya

Implementation of curriculum based environmental in primary school of Lidah Kulon 1 Surabaya is implementing curriculum design has been developed systematically in the planning stage. At this stage of learning in the classroom and support programs that have been planned to run in environments based classes that implement the integrity of the system, which means based learning environment inserted in each subject. However, the implementation of curriculum based environmental in primary school of Lidah Kulon 1 Surabaya also be said to lack good run in accordance with the plan, because the teacher as a facilitator or supplier curriculum to student achievement lack antuisias high attitude.

Support programs outside the classroom such as extracurricular activities entrepreneur product, clean friday, composter, and SEMUT activities. Implementation of the support program is an activity to foster care and cultural character of the environment on school students and all citizens in primary school of Lidah Kulon 1 Surabaya. But on the entrepreneur extracurricular activities not all students participate, only students who have the will, even though this is a developing extracurricular school icon, all students should know the management of the aloe vera plant.

3. Evaluation Curriculum Based Environment in Primary School Of Lidah Kulon 1 Surabaya.

Evaluation curriculum based Environmental at primary school of Lidah Kulon 1 Surabaya as early in the planning activities that hold a coordination meeting involving all stakeholders every six months or once three motnths. While that is not structured evaluation conducted by the Headmaster, that is always check all the school in the morning and conduct supervision to their class teachers so 
that errors can be corrected as soon as possible.

The evaluation was conducted to determine progress learning activities undertaken in the classroom and support programs that have been planned are implemented as expected or in need of repair.

\section{REFERENCES}

(1) Abdullah and Halim. 2010. Development of Instrument Measuring the Level of Teachers Pedagogical Content Knowledge (PCK) in Environmental Education. Procedia Social and Behavioral Sciences. Volume 134, 9 June 2010, Pages 174-178

(2) Adam, Ahmad F.B. 2014. Analisis Implementasi Kebijakan Kurikulum Berbasis Lingkungan Hidup pada Program Adiwiyata Mandiri di SDN Dinoyo 2 Malang. Jurnal Kebijakan dan Pengembangan Pendidikan Volume 2, Nomor 2, Juli 2014.

(3) Alpusari, Mahmud. 2013. Analisis Kurikulum Pendidikan Lingkungan Hidup Pada Sekolah Dasar Pekanbaru. Jurnal Primary Program Studi Pendidikan Guru Sekolah Dasar Fakultas Keguruan dan Ilmu Pendidikan Universitas Riau Volume 2 Nomor 2.

(4) Hamalik, Oemar. 2008. Dasar-Dasar Pengembangan Kurikulum. Bandung: Remaja Rosdakarya.

(5) Mahmuddin. 2010. Menciptakan Lingkungan Pembelajaran yang Kondusif. Online https://mahmuddin.wordpress.com/2010/0 2/18/menciptakan-lingkunganpembelajaran-yang-kondusif/. 1 Desember 2016, pukul 16.34.

(6) Miles, Huberman and Saldana. 2014. Qualitative Data Analysis: A Methods Sourcebook Edition 3. California: Sage Publication, Inc.

(7) Moreno, Ciro Hernando Parra, etc. 2011. Education for Environment Care:
Contribution Through Human ecology. Procedia Social and Behavioral Sciences: Volume 15, Pages 3912-3915

(8) Sideris, Michail Ch, etc. 2015. Evaluating the Educational Environment of an International Animal model-based Wet Lab Course for Undergradute Students. Annals of Medicine and Surgery: Volume 12, Pages 8-17.

(9) Sirait, Antay. 2011. Pemprov Jabar antisipasi Dampak Pembangunan Bandara. Website Resmi Pemprov Jabar.

(10) Sugiyono. 2015. Metode Penelitian: Pendekatan Kuantitatif, Kualitatif, dan R\&D. Bandung: Alfabeta.

(11) TIM Adiwiya Tingkat Nasional. 2012. Panduan Adiwiyata Sekolah Peduli dan Berbudaya Lingkungan. Jakarta: Kerjasama Kementerian Lingkungan Hidup dengan Kementerian Pendidikan dan Kebudayaan

(12) Yin, Robert K. 2011. Studi Kasus: Desain dan Metode. Jakarta: PT Raja Grafindo Persada. 